\title{
Her Majesty's Government's pleasure: providing appropriate community intervention can improve care and save money
}

\author{
Commentary on... Offender health ${ }^{\dagger}$
}

Mike Harris ${ }^{1}$

The Psychiatrist (2010), 34, 411-412, doi: 10.1192/pb.bp.110.032235

${ }^{1}$ Rampton Hospital, Retford

Correspondence to Mike Harris (Mike.Harris@nottshc.nhs.uk)

\begin{abstract}
Summary In answer to Louis Appleby's editorial, I am proposing that the role of mental health services in offender healthcare is to improve people's mental health and it is the role of the courts and the government to reduce the prison population. I also argue that with a reinvestment of existing resources into prison mental health we can reduce admission to expensive medium secure and low secure placements, save money and further reinvest in better care.
\end{abstract}

Declaration of interest $\mathrm{M} . \mathrm{H}$. manages the largest forensic service in the country covering high, medium and low secure services, and also provides prison healthcare services to 13 prisons.
Appleby $^{1}$ emphasises how the reforms in community care for mental health have transformed the environment. $\mathrm{He}$ then throws out the challenge to those of us providing offender healthcare services to respond to a similar set of goals and improve care for people with mental ill health, substance misuse and intellectual disability in the offender system at a time of severe budgetary constraints and cuts.

Over the past 25 years forensic mental health services have mushroomed, largely driven by a commercial sector hungry for profits at a time of increased National Health Service (NHS) spending and reduction in NHS beds. Forensic units have become, in many cases, the new and very expensive asylums.

\section{Reducing the number of people in prison - but at what cost to mental health services?}

Appleby challenges us to reduce the number of people in prison, by diversion, where appropriate, into mental health, learning disability and substance misuse services. He points out that $7 \%$ of sentenced male prisoners have psychosis, rising to $10 \%$ of remand male prisoners, and $14 \%$ of women. He also points out that two-thirds of people in prison have taken illicit drugs in the year before imprisonment, and a third were drinking heavily before imprisonment. However, the figures are based on an out-of-date survey, ${ }^{2}$ and many of the prisoners who have experienced a psychotic episode have also taken substances, rather than having an illness such as schizophrenia.

†See editorial, pp. 409-410, this issue.
Appleby suggests that we could reduce the prison population with appropriate leadership, staffing and care. However, is this the correct formula? The Lord Chancellor has outlined his view that prison populations could and should be reduced, and argues that prison does not work. Is the correct way forward to divert people from the criminal justice system into mental health services, or should we, as Szasz $^{3,4}$ and others have argued in the past, allow the criminal justice system to operate where appropriate, allow people to take full responsibility for their offending and provide treatment separately?

\section{Appropriate community care in the prison healthcare system can improve care}

We can reduce costs, relapse and further offending by providing appropriate treatment at all levels of the criminal justice system.

If we accept the principle that all are entitled to proper mental health services, regardless of offending, we can then deliver appropriate community care in the community, in police cells and in prisons. By providing this to the vast majority of offenders who are, if picked up early enough in their sentence, willing and able to consent to treatment, we can treat people's mental health problems in an environment dictated by their offending history. This in turn would reduce the use of forensic in-patient facilities which are, of course, far more costly than the criminal justice system, and have only those patients in the forensic in-patient facilities who require admission because of the severity of their illness, or because of their refusal to accept treatment on a voluntary basis. We could make further savings by ensuring 
that the mental health of prisoners is stabilised before they are due for release, and that community follow-up is arranged and fully in place before release, including postrelease support and mentoring, as currently undertaken by the St Giles Trust. ${ }^{5}$

The money saved, particularly from medium and low secure beds, could be re-invested in better mental health and learning disability services, although, of course, at a time of budgetary cuts it will take some very sensible and joined-up commissioning thinking to ensure that the money is not just re-invested in other parts of the health service. This model is not a new one, and has been tried and demonstrated to work. We therefore need a model based on the previous National Service Framework work in community mental health. ${ }^{6}$

Mental health in the community should be provided to all, including offenders. In line with the Bradley report, ${ }^{7}$ joined-up working across mental health services should be promoted. People whose needs are predominantly those of treating their mental illness, personality disorder, intellectual disability or substance misuse should be removed from the criminal justice system. For those whose offending warrants it, we should not interfere with the appropriate judicial process but ensure that the community mental health teams liaise properly with the providers of mental health in the offender health services. Furthermore, those services must be properly resourced to provide timely and active treatment within the offender system so as to minimise the referrals out to expensive hospital placements and allow reinvestment of that money. Finally, offender health teams should make timely, appropriate arrangements to set up follow-up and support for people leaving prisons and returning to the community.
We should celebrate the appointment of Louis Appleby to the post of National Clinical Director for Health and Criminal Justice and the coordination that this role brings. However, although much of Appleby's article is music to my ears, we need to decide whether our purpose is to reduce the prison population or provide improved mental healthcare. I believe we can and should focus on the latter, and help both the NHS and criminal justice system provide better care at a lower cost, letting the courts and the government sort out sentencing policy.

\section{About the author}

Mike Harris is Executive Director Forensic Services, Chief Officer for high secure services, consultant forensic psychiatrist, Philip Champ Management Centre, Rampton Hospital, Retford.

\section{References}

1 Appleby L. Offender health: the next frontier. Psychiatrist 2010; 34 409-10.

2 Singleton N, Meltzer H, Gatward R, Coid J, Deasy D. Psychiatric Morbidity among Prisoners. Office for National Statistics, 1999.

3 Szasz TS. Insanity: The Idea and Its Consequences. John Wiley \& Sons, 1987.

4 Szasz TS. The Medicalisation of Everyday Life: Selected Essays. Syracuse University Press, 2007.

5 Verkaik R. A big issue: what should we do about Kenneth? Independent 2010, 28 April.

6 Department of Health. National Service Framework for Mental Health: Modern Standards and Service Models. Department of Health, 1999.

7 Lord Bradley. Lord Bradley's Review of People with Mental Health Problems or Learning Disabilities in the Criminal Justice System. Department of Health, 2009. 